\title{
Kesejahteraan Spiritual Keluarga Pasien Stroke dan Kaitannya dengan Depresi
}

\author{
Muhamad Zulfatul A'la' ${ }^{1}$ Komarudin ${ }^{2}$, Defi Efendi ${ }^{3}$
}

${ }^{1}$ IImu Keperawatan, Universitas Jember, JI. Kalimantan 37 Jember, Indonesia

2,3IImu Keperawatan, Fakultas IImu Kesehatan, Universitas Muhammadiyah Jember, Jl. Karimata 49 Jember, Indonesia

\begin{abstract}
Abstrak
Penyakit stroke merupakan permasalahan utama dalam perawatan paliatif. Pengkajian spiritual dan depresi keluarga pasien adalah elemen penting dalam proses perawatan paliatif pasien stroke. Tujuan penelitian ini mengetahui gambaran kesejahteraan spiritual keluarga dan kaitannya dengan depresi. Desain penelitian ini adalah cross-sectional dengan jumlah responden 44 keluarga pasien stroke. Penelitian menggunakan spiritual well-being (SWBS) untuk melihat kesejahteraan spiritual keluarga dan Center for Epidemiologycal Studies Depression Scale (CES-D) untuk mengukur depresi keluarga. Hasil penelitian menyebutkan kesejahteraan spiritual keluarga pasien stroke dalam kategori tinggi dan depresi dalam kategori sedang. Terdapat hubungan antara kesejahteraan spiritual dan depresi pada keluarga pasien stroke $(p=0,000)$. Saran penelitian ini adalah perlu adanya pengkajian secara komprehensif mengenai kesejahteraan spiritual dan depresi pada keluarga pasien stroke serta perlu adanya penelitian tentang intervensi terhadap keluarga dalam upaya penurunan depresi dan peningkatan kesejahteraan spiritual.
\end{abstract}

Kata Kunci: depresi, kesejahteraan spiritual, keluarga pasien stroke, keperawatan paliatif

\section{Spiritual Wellbeing of Stroke Family Caregiver and its Relationship with Depression}

\begin{abstract}
Stroke is a one of major problem in palliative care. Spiritual and depression assessment of the family is an important element in the process of palliative care for stroke survivors. The purpose of this study was to know the description of the spiritual well-being among stroke family caregiver family and its relationship with depression. This study used cross-sectional design. Spiritual well-being scale (SWBS) was used to see the spiritual well-being of the family and the Center for Epidemiologycal Studies Depression Scale (CES-D) to measure depression and was filled in by 44 Stroke families. The results of the study reported that the spiritual well-being of stroke family caregiver was in the high category and depression in the medium category. There was a relationship between the spiritual well-being of the family and depression in stroke patients $(p=0.000)$. This study suggest a comprehensive assessment of the spiritual well-being and depression in stroke family and the need for future research about family interventions to decrease depression and increase spiritual well-being
\end{abstract}

Keywords: depression, spiritual well-being, stroke family, paliative care

Info Artikel:

Artikel dikirim pada 7 Oktober 2015

Artikel diterima pada 7 Oktober 2015 


\section{PENDAHULUAN}

Perkembangan Keperawatan paliatif kekinian berkembang pesat dengan banyaknya penyakit terminal dengan kebutuhan perawatan end-of-life(1). Keperawatan paliatif juga mengarahkan terhadap perawatan yang berfokus terhadap keluarga. keluarga dianggap sebagai elemen penting dalam proses perawatan terhadap pasien dalam keadaan terminal untuk menuju kematian yang damai. Selain penyakit kanker, penyakit stroke merupakan permasalahan utama dalam perawatan paliatif(2).

Stroke adalah salah satu masalah kesehatan yang serius. Tahun 2015, WHO mengestimasi terdapat 20 juta orang yang akan meninggal karena stroke. Proporsi kematian stroke adalah 15,4\% pada tahun 2007. Setiap 7 orang yang meninggal di Indonesia, 1 diantaranya disebabkan karena stroke(3).

Stroke sering terjadi mendadak dan tidak terprediksi(4). Hal ini membawa dampak yang berat bagi keluarga, terutama pasangan hidupnya(5). Seperti halnya penelitian sebelumnya yang dilakukan pada 114 pasangan pasien yang mengalami stroke kejadian kecemasan dengan prevalensi sekitar $27,6 \%-28,9 \%(3)$.

Masalah Spiritual merupakan masalah mandiri keperawatan dan diselesaikan dengan intervensi mandiri(6). Dukungan spiritual tidak hanya terbatas dalam praktik keagamaan seperti halnya membaca kitab suci maupun berdoa, akan tetapi dukungan spiritual juga mengacu pada menenangkan, menghibur, mendengarkan, menghormati privasi serta membantu mencari makna dan tujuan hidup keluarga(7). Depresi adalah salah satu faktor yang mempengaruhi spiritual(7).

Proses Keperawatan end-of-life diperlukan di RSD Soebandi jember karena merupakan Rumah sakit daerah tipe B sebagai rujukan untuk wilayah bagian timur provinsi Jawa Timur. Peneliti mendapatkan data dari rekam medis bahwa jumlah kunjungan pasien dengan diagnosa Stroke selama bulan Januari-Agustus 2013 sebanyak 408 pasien.

Hasil wawancara dengan tiga orang perawat ada bulan Agustus 2013 di Ruang Melati RSD Dr. Soebandi, menyebutkan bahwa dukungan spiritual sangat perlu untuk keluarga maupun pasien. Hasil wawancara dengan perawat pelaksana dan kepala ruang menyebutkan bahwa pernah terjadi histeria keluarga terhadap kejadian kematian pasien. Hal ini dapat mengindikasikan adanya berduka yang tidak efektif dari keluarga. perawat mengatakan perlu adanya intervensi untuk mempersiapkan berduka yang efektif (anticipatory grieving).

Dari data pengamatan selama tiga hari didapatkan hampir $90 \%$ pasangan suami/istri mendampingi pasien di ruang perawatan. Hasil wawancara pada keluarga mengatakan bahwa kebutuhan psikososial merupakan hal yang penting salah satunya dalam upaya menurunkan stres. Dari data dan fakta di atas, perlu adanya penelitian dalam melihat kesejahteraan spiritual keluarga pasien stroke dan kaitannya dengan depresi. Tujuan penelitian ini adalah untuk mengetahui gambaran kesejahteraan spiritual keluarga pasien stroke dan hubungan antara kesejahteran spiritual dengan depresi keluarga pasien stroke.

\section{BAHAN DAN METODE}

Penelitian ini merupakan penelitian deskriptif korelasional. Penelitian ini terdiri dari dua variabel yaitu variabel bebas dan satu variabel tergantung. Variabel bebas penelitian ini adalah tingkat kesejahteraan spiritual yang diukur menggunakan kuesioner SWBS (spiritual well-being scale) pada keluarga pasien dengan stroke yang dikembangkan oleh Paloutzian(8). Sedangkan variabel tergantung pada penelitian ini adalah depresi keluarga pasien stroke yang diukur menggunakan alat kuesioner yang dimodifikasi dari kuesioner center for epidemiologycal studies depression scale (CES-D) yang terdiri dari 20 item pertanyaan meliputi gejala-gejala gangguan depresi yang sesuai untuk deteksi awal pada populasi pasien dengan penyakit kronik(9).

Populasi yang ditargetkan pada penelitian ini adalah keluarga pada pasien dengan stroke yang di rawat di RSD Soebandi Jember. Rata-rata jumlah populasi dalam dua bulan adalah 50 pasien. Sampel dipilih dengan cara consecutive sampling, yaitu jumlah sample yang dipilih dari urutan pasien yang dirawat. Penentuan sample menggunakan kriteria inklusi: keluarga pada pasien dengan diagnosa stroke oleh dokter yang dirawat lebih dari dua hari, keluarga adalah orang yang terdekat yaitu suami/istri pasien, atau anak kandung pasien atau adik/kakak kandung pasien, keluarga yang bisa membaca dan menulis, sedangkan kriteria eksklusi: keluarga dengan penyakit jiwa yang didiagnosa oleh dokter. Jumlah sampel yang dipakai menggunakan rumus Slovin adalah sebanyak 44 keluarga pasien stroke. 


\section{HASIL DAN BAHASAN}

Hasil penelitian menggambarkan tentang karakterisitik responden keluarga pasien stroke, gambaran tentang kesejahteraan spiritual dan depresi keluarga pasien stroke dan hubungan antara kesejahteraan spiritual dan depresi keluarga pasien stroke di RSD Soebandi Jember Bulan April 2014.

\section{Karakteristik Responden}

Sampel total dalam penelitian ini adalah 44 orang. Karakteristik responden (jenis kelamin, pendidikan, status pernikahan dan hubungan dengan pasien) dalam penelitian ini terlihat dalam Tabel 1.

Tabel 1. Karakteristik Responden berdasarkan Jenis Kelamin, Pendidikan, Status Pernikahan dan Hubungan dengan Pasien di Ruang Melati, RSD Soebandi Jember pada April 2014

\begin{tabular}{lcc}
\hline Karakteristik & $\mathbf{n}$ & $\%$ \\
\hline Jenis Kelamin & 7 & 84,1 \\
$\quad$ Laki-Laki & 37 & 15,9 \\
$\quad$ Perempuan & & \\
Tingkat Pendidikan & 3 & 6,8 \\
$\quad$ Tidak Sekolah & 1 & 2,3 \\
SD/ Sederajat & 10 & 22,7 \\
SMP/Sederajat & 27 & 61,4 \\
SMA/Sederajat & 3 & 6,8 \\
$\quad$ Diploma/Lebih Tinggi & & \\
Status Pernikahan & 40 & 90,9 \\
$\quad$ Menikah & 4 & 9,1 \\
$\quad$ Tidak Menikah & & \\
Hubungan dengan Pasien & 6 & 13,6 \\
$\quad$ Suami/lstri & 32 & 72,7 \\
$\quad$ Adik/Kakak Kandung & 0 & 0 \\
$\quad$ Ayah/lbu Kandung & 6 & 13,6 \\
$\quad$ Anak & 0 & 0 \\
$\quad$ Keluarga Lain/Orang Lain Yang & & \\
$\quad$ Merawat Pasien & &
\end{tabular}

Responden penelitian terlihat dalam Tabel 1 terbanyak adalah perempuan dengan $84,1 \%$, tingkat pendidikan terbanyak adalah SMA atau sederajat dengan $61,4 \%$. Status pernikahan responden terbanyak adalah sudah menikah dengan 90,9\% dan hubungan keluarga dengan pasien terbanyak adalah adik/kakak kandung dengan $72,7 \%$. Ratarata umur responden adalah $39,1 \%$ dan rata-rata lama merawat pasien adalah 3,14 hari.

Hasil karakteristik responden menunjukkan bahwa keluarga pasien stroke adalah perempuan. $\mathrm{Hal}$ ini sesuai dengan penelitian sebelumnya yang menyebutkan bahwa perempuan lebih "care"
Tabel 2. Karakteristik Responden berdasarkan Umur dan di Ruang Melati, RSD Soebandi Jember pada April 2014

\begin{tabular}{lcc}
\hline Karakteristik & Rata-Rata & SD \\
\hline Umur & 39,1 & 5,13 \\
Lama merawat pasien & 3,14 & 0,73 \\
\hline
\end{tabular}

terhadap pasien di rumah sakit, sehingga banyak perempuan sebagai istri, kakak/adik maupun anak dari pasien stroke(4). Namun dalam penelitian tersebut tidak disebutkan bahwa ada perbedaan kesejahteraan spiritual antara laki-laki dan perempuan sehingga jumlah mayoritas jenis kelamin tidak mempengaruhi tingkat kesejahteraan spiritual keseluruhan(4).

Status pernikahan responden terbanyak adalah sudah menikah, hal ini tidak berpengaruh terhadap kesejahteraan spiritual. Velasco dan Rioux menyebutkan bahwa kesejahteraan spiritual dipengaruhi oleh tingkat perkembangan(10). Berdasarkan Tabel 2 rata-rata umur pasien dalam penelitian ini adalah 39 tahun dengan rata-rata lama merawat pasien stroke di rumah sakit selama 3 hari. Dalam penelitian ini kriteria inklusi responden ditentukan sesuai dengan umur dalam tingkat perkembangan dewasa dan dewasa tua, sehingga tidak akan mempengaruhi tingkat kesejateraan spiritual.

\section{Gambaran Kesejahteraan Spiritual dan Depresi Keluarga Pasien Stroke di RSD Soebandi Jember}

Rata-rata skor kesejahteraan spiritual dan depresi keluarga pasien stroke di RSD Soebandi Jember terlihat dalam Tabel 3.

Tabel 3. Gambaran Skor Kesejahteraan Spiritual dan Depresi Keluarga Pasien Stroke di RSD Soebandi Jember bulan April 2014

\begin{tabular}{lcc}
\hline \multicolumn{1}{c}{ Variabel } & Rata-Rata & SD \\
\hline Kesejahteraan Spiritual & 99,91 & 2,24 \\
Depresi & 55,79 & 2,46 \\
\hline
\end{tabular}

Tabel 3 menunjukkan tingkat kesejahteraan spiritual keluarga pasien stroke adalah 99,91 $(2,24)$ dan masuk dalam kategori kesejahteraan spiritual tinggi, hal ini sesuai dengan pendapat Paloutzian yang menyebutkan bahwa rata-rata kesejahteraan spiritual pada pasien maupun keluarga yang sedang dirawat di rumah sakit adalah 99(8). Pendapat ini diperkuat oleh penelitian Isen yang menyebutkan bahwa tingkat kesejahateraan spiritual pasien dan 
keluarga dengan penyakit terminal dalam kategori tinggi(11). Tabel 3 juga memperlihatkan tingkat depresi keluarga pasien stroke dalam kategori tinggi. Hal ini sesuai dengan penelitian Burton dan Payne yang menyebutkan bahwa tingkat depresi keluarga pasien stroke tinggi(12).

\section{Hubungan antara Kesejahteraan Spiritual dan Depresi Keluarga Pasien Stroke}

Hubungan antara kesejahteraan spiritual dan depresi keluarga pasien stroke di RSD Soebandi terlihat dalam Tabel 4.

Tabel 4. Uji Korelasi antara Kesejahteraan Spiritual dan Depresi Keluarga Pasien Stroke di RSD Soebandi Jember, April 2014

\begin{tabular}{lcccc}
\hline \multicolumn{1}{c}{ Variabel } & Rata-Rata & SD & r & p-value \\
\hline $\begin{array}{l}\text { Kesejahteraan } \\
\text { Spiritual }\end{array}$ & 99,91 & 2,24 & 0,896 & 0,000 \\
Depresi & 55,79 & 2,46 & & \\
\hline
\end{tabular}

Tabel 4 memperlihatkan bahwa terdapat hubungan antara kesejahteraan spiritual dan depresi pada keluarga pasien stroke $(p=0,000)$. Uji kerekatan didapatkan nilai $-0,896$ sehingga dapat diinterpretasikan bahwa semakin tinggi skor spiritual keluarga akan semakin rendah tingkat depresi keluarga dengan nilai kerekatan 0,896. $\mathrm{Hal}$ ini sesuai dengan penelitian Strada-Russo yang menyebutkan bahwa ada hubungan yang bermakna antara kesejahteraan spiritual dan tingkat depresi pada keluarga pasien penyakit terminal(7). Penelitian Tan, et al juga menyebutkan bahwa tingkat depresi sangat berkaitan erat dengan spiritual seseorang(13).

Depresi adalah gangguan mood (perasaan dasar), kondisi emosional berkepanjangan yang mewarnai seluruh proses mental (berpikir, berperasaan, dan berprilaku) seseorang. McDowell \& Nowell menjelaskan bahwa pola depresi dapat disebut sebagai dysfungsional beliefs, yaitu faktor kerentanan seseorang dimana ketika seseorang mengalami suatu peristiwa yang negatif (stress), seseorang cenderung menjadi depresi dan menginterpretasikan kejadian atau pengalaman tersebut sebagai suatu yang negatif(14). Keadaan negatif ini dapat mempengaruhi pemahaman terhadap diri, orang lain dan terhadap Tuhan. Ketika depresi muncul, spiritual seseorang akan terganggu akibat pemaknaan terhadap diri, orang lain dan Tuhan berubah. Peristiwa negatif, pengalaman yang lalu akan mempengaruhi penerimaan terhadap eksistensi diri. Ketidakterimaan terhadap keadaan juga akan memicu marah terhadap Tuhan, sehingga aspek religiusitas akan terganggu(15).

Penelitian ini berguna sebagai landasan untuk mendapatkan data psikologis keluarga pasien stroke. Hal ini berkaitan dengan pemberian informasi terhadap keluarga, ketika perawat mampu untuk mengkaji tingkat depresi dan tingkat spiritualitas, perawat akan mampu memberikan intervensi dengan waktu yang tepat, sehingga dapat memaksimalkan intervensi yang diberikan terhadap keluarga.

\section{SIMPULAN DAN SARAN}

Tingkat kesejahteraan spiritual keluarga pasien stroke dalam kategori tinggi 99,91 $(2,24)$. Tingkat Depresi pasien stroke dalam kategori tinggi 55,76 $(2,46)$. Ada hubungan antara tingkat kesejateraan spiritul dan depresi pada keluarga pasien stroke $(p=0,000)$ dengan nilai keeratan 0,896 . Semakin tinggi kesejahteraan spiritual, semakin rendah depresi keluarga pasien stroke. Saran dalam penelitian ini adalah perlu adanya pengkajian secara komprehensif mengenai kesejahteraan spiritual dan depresi pada keluarga pasien stroke serta untuk penelitian selanjutnya perlu adanya intervensi terhadap keluarga dalam upaya penurunan depresi dan peningkatan kesejahteraan spiritual.

\section{RUJUKAN}

1. Wright LM. Spirituality, Suffering, and Illness: Ideas for healing. Philadelphia: F.A. Davis Comp; 2005.

2. Friedman M. Keperawatan Keluarga Teori dan Praktek Jakarta: EGC; 2007.

3. Kementerian Kesehatan. Buletin Jendela Data dan Informasi. 2012:1-48.

4. Haley WE, Allen JY, Grant JS, Clay OJ, Roth DL. Problems and Benefits Reported by Stroke Family Caregivers: Results from a Prospective Epidemiological Study. Stroke. 2010;40(6):2129-33.

5. Wallace $S$, Christianna S. Emotional and Physical Health of Informal Caregivers of Residents at ... Journal of Gerontology. 2008;63B(3):171-83.

6. CNA. Spirituality, Health and Nursing Practice Vol. 5. In Canada; 2009:1-4.

7. Strada-Russo E. Spirituality as a Protective Factor in Complicated Bereavement. San fransisco; 2006. 
8. Paloutzian RF, Bufford RK, Wildman AJ. Spiritual Well-Being Scale: Mental and Physical Health Relationships. In: Oxford Textbook of Spirituality in Healthcare. 2012.p.353-8.

9. Radloff LS. The CES-D scale: A self-report depression scale for research in the general population. Appl Psychol Meas. 1977;1(3): 385-401.

10. Velasco-Gonzalez L, Rioux L. The Spiritual WellBeing of Elderly People: A Study of a French Sample. J Relig Health. 2014;53(4):1123-37.

11. Isen KD, Dysvik E, Hansen BS. The meaning of family members' presence during intensive care stay: A qualitative study. Intensive Crit Care Nurs. 2009;25(4):190-8.

12. Burton $C R$, Payne S. Integrating palliative care within acute stroke services: developing a programme theory of patient and family needs, preferences and staff perspectives. BMC palliat care. 2012;11(1):22.

13. Tan HM, Wilson A, Olver I, Barton C. The experience of palliative patients and their families of a family meeting utilised as an instrument for spiritual and psychosocial care: A Qualitative study. BMC palliat care. 2011;10(1):7.

14. Mc Dowell J, Nowell DK. Dimensions of the event that influence psychological distress; An evaluation \& synthesis of the literature. In $\mathrm{H}$. B. Kaplan .(Ed). Psychosocial Stress: Trends in Theory \& Research. New York: Academic Press; 2001:33-103.

15. Fisher JW. Assesing \& Nurturing Spiritual WellBeing via Education. Ballarat. 2009:1-266. 